\title{
Nitrogen and phosphorus balances on Finnish dairy farms
}

Hanna Virtanen

Valio Ltd, Farm Services, PO Box 10, FI-00039 Valio, Finland. Present address: MTT Agrifood Research Finland, Environmental Research, FI-31600 Jokioinen, Finland

Juha Nousiainen

Valio Ltd, Farm Services, PO Box 10, FI-00039Valio, Finland, e-mail: juha.nousiainen@valio.fi

\begin{abstract}
The calculation of whole-farm nutrient balance is an effective and simple method for estimating the potential nutrient loading from dairy farming into the environment. In Finland, however, the published results based on larger number of farms are still lacking. In this study whole-farm nitrogen $(\mathrm{N})$ and phosphorus $(\mathrm{P})$ balances on Finnish dairy farms were studied based on short-cut data for the year 2002. The survey was targeted to 1260 dairy farms, located all over Finland. Of the 386 replies received, 319 were used for subsequent statistical analyses. The association between selected farm variables and nutrient balance was studied using regression analysis and a sensitivity coefficient was calculated for each regression slope. The average ( \pm standard deviation) whole-farm nutrient balance for $\mathrm{N}$ and $\mathrm{P}$ was $109( \pm 41.3)$ and $12( \pm 7.2) \mathrm{kg}$ $\mathrm{ha}^{-1}$, respectively. The most responsive factors affecting the nutrient balances were total nutrient and fertilizer import per ha, followed by animal density, milk export per ha and concentrate import per ha. The results suggested that nutrient surpluses could be controlled more easily in combined crop and milk than in specialised milk production. It is concluded that nutrient surplus on Finnish dairy farms is markedly lower than that on areas with intensive production in central European countries. However, when nutrient balances were extrapolated to comparable production intensity as in central Europe, the level of the surpluses was equal.
\end{abstract}

Key words: dairy farming, nutrient balance, nitrogen, phosphorus

\section{Introduction}

In Finland, as elsewhere within the European Union (EU), there is increasing public concern about the environmental impact of animal agriculture, especially in areas with intensive dairy farming. Studies examining the environmental impacts of milk products throughout their whole life cycle have shown that a major part of the effects arises from raw milk production on dairy farms (Høgaas Eide 2002, Voutilainen et al. 2003). Moreover, 
Vol. 14 (2005): 166-180.

these studies clearly indicate that the most important environmental impacts caused by dairy farming are eutrophication and groundwater pollution, following non-point phosphorus $(\mathrm{P})$ and nitrogen $(\mathrm{N})$ leaching and runoff from farming systems. Estimates based on data of Voutilainen et al. (2003) suggest that up to $8-10 \%$ of the total eutrophication potential ( $\mathrm{N}$ and $\mathrm{P}$ ) in Finland may result from milk production, which is much higher than its contribution to global warming $\left(4 \%, \mathrm{CO}_{2}\right.$ and $\mathrm{CH}_{4}$ losses) or acidification potential $\left(3 \%, \mathrm{NO}_{\mathrm{x}}\right.$ and $\mathrm{SO}_{2}$ losses).

Most of the Finnish dairy farms have been involved in the Agri-Environmental Programme (AEP) of the European Union since 1995, in which voluntary environmental measures (restricted fertilizer use, buffer zones, constructed wetlands, etc.) are subsidised. However, follow-up studies suggest that positive effects on the quality of natural waters are lacking until now (Räike et al. 2003, 2004). This may be due to long-term accumulation of $\mathrm{P}$ and $\mathrm{N}$ in soil and sediments of lakes and rivers, inefficiency of the measures adopted within AEP or increased nutrient import to arable land caused by the gradual shift towards more intensive animal agriculture.

Experiences from Europe (e.g. Van Bruchem et al. 1999, Van Keulen et al. 2000, Oenema et al. 2003) and the United States (e.g. Van Horn et al. 1996, Spears et al. 2003a, b) demonstrate that a systematic analysis of whole-farm balances of nutrients (WFB; the difference between nutrient flows into and out of a dairy farm) as a first step is essential in improving the efficiency of nutrient use in milk production. The whole-farm balance method is simple and provides a practical way in diagnosing non-point leaching potential connected to animal agriculture. However, while WFB along with soil surface balances are often considered as a direct measure of nutrient leaching potential, the absolute magnitude of nutrient leakage varies due to variability in precipitation, soil type and cultivation practises (Schröder et al. 2003, Ekholm et al. 2005, Salo and Turtola, unpublished results).

Published research on WFB for $\mathrm{N}$ and $\mathrm{P}(\mathrm{N}-$ WFB and P-WFB) on dairy farms in Finland is still limited and the datasets are based on results from a few farms or from a specific area (e.g. Väisänen 1996, Poikela 2000). Increasing amount of data is available from elsewhere in Europe (e.g. Van Keulen et al. 2000, Swensson 2003) and the United States (Spears et al. 2003a, b). The number of dairy farms in Finland is decreasing with simultaneous increase in production intensity, whether expressed as milk yield per cow, farm or land area. Concurrently, the dairy sector is faced with stricter environmental legislation and public demands to conserve the agricultural landscape and clean natural waters. Therefore, finding effective and simple methods to control the potential leakage of nutrients from dairy farming systems is essential in improving the performance of the milk production chain.

The objective of this study was to calculate WFB for $\mathrm{N}$ and $\mathrm{P}$ on dairy farms in Finland and to study the relations between WFB and selected farm variables (nutrient import/export, production intensity and farm type).

\section{Material and methods}

\section{Farm survey}

The data for this study were collected in June and July 2003 through a questionnaire addressed to 1260 farms (6.5\% of all dairy farms in Finland on 1.5.2002) located across Finland. The questionnaire was formulated as short and simple as possible to encourage the farmers to respond. In the introductory letter the WFB method and single queries in the questionnaire were described carefully. Queries on quantities and types of purchased fertilisers, manure, feeds, bedding, seeds and animals were included in the questionnaire. In addition, quantities of crops and numbers and types of animals sold and amounts of manure exported from the farm were monitored. Monthly quantities of milk delivered to dairies and milk crude protein concentration $(\mathrm{CP})$ were collected from the respective dairy records. Finally, information on some farm characteristics was requested, i.e. main pro- 
duction branch (milk vs. meat), type of production (conventional vs. organic) and land use. All information referred to the year 2002.

\section{Calculation of nutrient balances}

A total of 386 replies (equivalent to $31 \%$ of the questionnaires distributed) were obtained, of which 8 were excluded because of inadequate information. Additionally, organic farms $(n=16)$ and farms that had used apatite for fertilization ( $\mathrm{n}$ =24) were excluded from the data. Quantities of nutrients in imported and exported materials were converted to kilograms of $\mathrm{N}$ and $\mathrm{P}$ according to data received from the feed industry, feed tables (concentrates, Tuori et al. 2002) and feed analyses (Valio Ltd., forages, grain), Kemira Grow-How Ltd. (fertilizers) or manure analyses (Viljavuuspalvelu Ltd.). Total $\mathrm{N}$ content in purchased seeds and feeds was calculated as $\mathrm{N}(\mathrm{kg})=$ crude protein $\mathrm{CP}$ $(\mathrm{kg}) \times 0.16$ (Tuori et al. 2002). P was invariably reported as total $\mathrm{P}$. Total $\mathrm{N}$ and $\mathrm{P}$ in exported/imported cattle were calculated from empty body weight of animals between 3-24 months of age (ARC 1980). The concentration of CP and P in gut contents was estimated at 150-200 and $8 \mathrm{~g}$ [kg dry matter $(\mathrm{DM})]^{-1}$, respectively, and DM content at $100 \mathrm{~g} \mathrm{~kg}^{-1}$ (ARC 1980). Total $\mathrm{N}$ and $\mathrm{P}$ in milk were calculated as:

$\mathrm{N}(\mathrm{kg})=\mathrm{CP}(\mathrm{kg}) \times 0.157$ (Tuori et al. 2002) and

$\mathrm{P}\left(\mathrm{g} \mathrm{kg}^{-1}\right)=0.45+0.133 \times \mathrm{N}\left(\mathrm{g} \mathrm{kg}^{-1}\right)(\mathrm{ARC}$ 1980).

Atmospheric deposition (N, P), biological fixation $(\mathrm{N})$ and volatile losses $(\mathrm{N})$ were not considered. Finally, the imports and exports of $\mathrm{N}$ and $\mathrm{P}$ were summed in a nutrient balance sheet constructed for this study.

\section{Statistical methods}

The distribution of variables in the data was analysed and unusual observations were removed from the data $[\mathrm{n}=19$, observations that deviated from the mean more than $2.5 \times$ standard deviation (SD)], because the validity of these field observations could not be verified. A total of 319 records were used for subsequent statistical analyses. The final data included 81, 117, 80 and 41 dairy farms from southern, western, eastern and northern part of Finland, respectively. The relationships between WFB for $\mathrm{N}$ and $\mathrm{P}$ and selected farm variables were studied by regression analysis using a model:

$$
\mathrm{Y}=\mathrm{A}_{0}+\mathrm{B}_{1} \mathrm{X}_{1}+\mathrm{B}_{2} \mathrm{X}_{2}+\ldots+\mathrm{B}_{\mathrm{n}} \mathrm{X}_{\mathrm{n}}+\mathrm{e}
$$

Where, $\mathrm{Y}$ is the response variable, $\mathrm{A}_{0}$ is the overall intercept, $B_{1 \ldots n}$ are the overall regression coefficients for continuous variables $X_{1 \ldots n}$ and $e$ is unexplained error. The models were evaluated with coefficient of variation that was adjusted for the degrees of freedom (Adj. $\mathrm{R}^{2}$ ) and the standard error of estimate (SEE). All statistical computations were conducted with STATISTICA 6.0 software (StatSoft Inc., Tulsa, USA).

The relative responsiveness of the farm variables was further evaluated by calculating a sensitivity coefficient, i.e. ratio of unit change in response variable $\mathrm{Y}$ to unit change in regression variable $X$. The data $(n=319)$ were also classified according to nutrient export (EX) and import (IM) ratio and milk production intensity (I, $\mathrm{kg}$ milk $\left.\mathrm{ha}^{-1}\right)$. EX was calculated as a proportion of nutrient export in crops of the total export. Farms with EX $<0.25$ and $\geq 0.25$ were classified as "mainly livestock" (M: n = 253 and 247) and "combined livestock \& crop" (C: $\mathrm{n}=66$ and 72 ) for $\mathrm{N}$ and $\mathrm{P}$, respectively. IM was calculated as the ratio of imported feed nutrients to estimated amount of feed nutrients used by livestock. Feed nutrient use was calculated from herd DM intake (DMI) using average dietary $\mathrm{N}$ and $\mathrm{P}$ concentrations of 25.6 (Huhtanen et al., unpublished results) and 4.74 (Yrjänen et al. 2003) g ( $\mathrm{kg} \mathrm{DM})^{-1}$, respectively. DMI $\left(\mathrm{kg} \mathrm{d}^{-1}\right)$ was estimated as DMI $=8.6+0.4 \times$ Milk yield $(\mathrm{kg}$ $\left.\mathrm{d}^{-1}\right)$. For non-lactating cattle, DMI was assumed to be $8.6 \mathrm{~kg} \mathrm{DM} \mathrm{d}^{-1}$ per animal unit. Production intensity of farms with I less than or equal to $4000 \mathrm{~kg}$ $\mathrm{ha}^{-1}$ was classified as "low" (L: $\left.\mathrm{n}=154\right)$; above that as "high" $(\mathrm{H}: \mathrm{n}=165)$. 
Vol. 14 (2005): 166-180.

\section{Results}

\section{Description of the dataset}

All farm variables showed wide variation and were normally distributed (Table 1). Mean herd size was 38.8 animal units (range 4.5-104.4), consisting mainly of dairy cows and replacement heifers (87.7\% of total). Total cropping area averaged 48.2 ha (range 4.3-160.0), of which 40.0 and $54.8 \%$ were used for cereal and forage production, respectively. Consequently, animal density varied between 0.25 and 2.03 units ha $^{-1}$ with an average value of 0.88 . Mean annual milk export per farm and cow was 188897 and $7616 \mathrm{~kg}$, giving a mean production intensity of 4349 (range 1 199-9 537) $\mathrm{kg} \mathrm{ha}^{-1}$.

\section{Whole-farm nutrient balances}

Imports, exports and resultant WFB for $\mathrm{N}$ and $\mathrm{P}$ are presented in Tables 2 and 3, respectively. The average $\left( \pm\right.$ SD) N-WFB was $109( \pm 41.3) \mathrm{kg} \mathrm{ha}^{-1}$, resulting from a difference between total $\mathrm{N}$ import of $144( \pm 46.5)$ and export of $36( \pm 20.1) \mathrm{kg} \mathrm{ha}^{-1}$. On average, a fraction of 0.70 and 0.26 of total $\mathrm{N}$ import consisted of fertilizers and feeds (mainly concentrates), respectively and the fractions of milk and crops in total $\mathrm{N}$ export were 0.64 and 0.16 , respectively. Total mean $\mathrm{P}$ import, export and balance were $18.5( \pm 7.9), 6.8( \pm 3.8)$ and $11.7( \pm 7.2)$; imports comprised fractions of 0.49 and 0.49 for fertilizers and feeds, respectively, and export 0.65 and 0.12 for milk and crops, respectively. Nutrient import in feeds was significantly higher than export in milk for both $\mathrm{N}\left(41.0 \mathrm{vs} .23 .1 \mathrm{~kg} \mathrm{ha}^{-1}, \mathrm{P}<\right.$ $0.001)$ and $\mathrm{P}\left(9.2\right.$ vs. $\left.3.9 \mathrm{~kg} \mathrm{ha}^{-1}, \mathrm{P}<0.001\right)$.

\section{Relationships between selected farm variables and whole-farm nutrient balances}

Table 4 shows the univariate regression relationships between selected farm variables and N-WFB.

Table 1. Description of the dairy farm data $(n=319)$.

\begin{tabular}{|c|c|c|c|c|c|c|}
\hline & Mean & Median & SD & Min & Max & $\begin{array}{l}\text { Mean in } \\
\text { Finland }^{\mathrm{d}}\end{array}$ \\
\hline \multicolumn{7}{|l|}{ Number of animals } \\
\hline Dairy cows & 24.7 & 22.0 & 10.85 & 3.0 & 62.0 & 16.9 \\
\hline Replacement dairy heifers & 13.9 & 12.0 & 8.10 & 0.0 & 55.0 & \\
\hline Replacement dairy heifers ${ }^{\mathrm{a}}$ & 23.8 & 24.2 & 7.66 & 0.0 & 49.8 & \\
\hline Growing cattle ( $>6$ months of age) & 4.3 & 0.0 & 9.06 & 0.0 & 80.0 & \\
\hline Calves $(<6$ months of age $)$ & 9.5 & 8.0 & 6.46 & 0.0 & 38.0 & \\
\hline Animal units ${ }^{\mathrm{b}}$ & 38.8 & 33.1 & 18.87 & 4.5 & 104.4 & 26.5 \\
\hline Animal density, animal units ha ${ }^{-1}$ & 0.88 & 0.84 & 0.322 & 0.25 & 2.03 & 0.74 \\
\hline \multicolumn{7}{|l|}{ Cropping area, ha } \\
\hline Cereals & 19.3 & 14.4 & 16.69 & 0.0 & 89.8 & \\
\hline Forage grass & 25.2 & 24.0 & 11.98 & 0.0 & 93.0 & \\
\hline Forage legume & 1.2 & 0.0 & 4.55 & 0.0 & 32.0 & \\
\hline Fallow & 2.4 & 0.0 & 4.82 & 0.0 & 47.0 & \\
\hline Total & 48.2 & 40.8 & 25.82 & 4.3 & 160.0 & 35.6 \\
\hline \multicolumn{7}{|l|}{ Milk yield, $\mathrm{kg} \mathrm{yr}^{-1 \mathrm{c}}$} \\
\hline Total & 188897 & 172773 & 88071.1 & 25250 & 520102 & 122474 \\
\hline Per cow & 7617 & 7688 & 1103.5 & 2756 & 10957 & 6880 \\
\hline Per cropping area & 4349 & 4054 & 1730.9 & 1199 & 9537 & 3437 \\
\hline
\end{tabular}


Virtanen, H. \& Nousiainen, J. Whole-farm N and P balances on Finnish dairy farms

Table 2. Average nitrogen $(\mathrm{N})$ import and export and whole-farm $\mathrm{N}$ balance on Finnish dairy farms $(\mathrm{n}=319)$.

\begin{tabular}{|c|c|c|c|c|c|}
\hline & Mean & Median & SD & Min & Max \\
\hline \multicolumn{6}{|l|}{$\mathrm{N}$ import } \\
\hline Fertilizers, kg & 4707.8 & 3960.0 & 2579.85 & 396.0 & 14592.5 \\
\hline Fertilizers, $\mathrm{kg} \mathrm{ha}^{-1}$ & 100.9 & 101.5 & 29.76 & 24.0 & 224.3 \\
\hline Seeds, $\mathrm{kg}$ & 36.0 & 25.7 & 41.10 & 0.0 & 295.0 \\
\hline Animals, kg & 13.4 & 0.0 & 38.90 & 0.0 & 458.1 \\
\hline Forages, $\mathrm{kg}$ & 101.3 & 0.0 & 500.87 & 0.0 & 5026.9 \\
\hline Mineral feeds, $\mathrm{kg}$ & 10.2 & 4.7 & 16.31 & 0.0 & 136.6 \\
\hline Concentrates, $\mathrm{kg}^{\mathrm{a}}$ & 1673.8 & 1405.1 & 1199.17 & 9.2 & 7321.8 \\
\hline Concentrates, $\mathrm{kg} \mathrm{ha}^{-1}$ & 38.6 & 34.1 & 25.20 & 0.2 & 145.1 \\
\hline Bedding, $\mathrm{kg}$ & 27.0 & 7.9 & 61.82 & 0.0 & 530.1 \\
\hline Total N import, kg & 6642.3 & 5651.5 & 3578.81 & 723.3 & 19021.6 \\
\hline Total $\mathrm{N}$ import, $\mathrm{kg} \mathrm{ha}^{-1}$ & 144.4 & 140.9 & 46.52 & 38.9 & 294.7 \\
\hline \multicolumn{6}{|l|}{$\mathrm{N}$ export } \\
\hline Manure, kg & 165.7 & 0.0 & 402.59 & 0.0 & 2465.0 \\
\hline Crops, kg & 362.8 & 0.0 & 1007.38 & 0.0 & 9664.8 \\
\hline Animals, $\mathrm{kg}$ & 132.7 & 116.4 & 96.72 & 0.0 & 633.8 \\
\hline Milk, kg & 1003.7 & 923.8 & 472.16 & 132.7 & 2793.1 \\
\hline Total N export, kg & 1664.9 & 1261.2 & 1304.54 & 219.7 & 11513.5 \\
\hline Total $\mathrm{N}$ export, $\mathrm{kg} \mathrm{ha}^{-1}$ & 35.8 & 30.9 & 20.09 & 10.5 & 143.9 \\
\hline $\mathrm{N}$ balance, kg & 4977.4 & 4346.3 & 2897.21 & -1531.1 & 16318.8 \\
\hline $\mathrm{N}$ balance, $\mathrm{kg}^{-1}$ & 108.6 & 104.5 & 41.30 & -19.1 & 231.1 \\
\hline
\end{tabular}

ancludes imported grain, by-products, commercial concentrates and protein supplements

Table 3. Average phosphorus (P) import and export and whole-farm P balance on Finnish dairy farms $(\mathrm{n}=319)$.

\begin{tabular}{|c|c|c|c|c|c|}
\hline & Mean & Median & SD & Min & Max \\
\hline \multicolumn{6}{|l|}{ P import } \\
\hline Fertilizers, $\mathrm{kg}$ & 426.9 & 360.0 & 303.96 & 0.0 & 1560.0 \\
\hline Fertilizers, $\mathrm{kg} \mathrm{ha}^{-1}$ & 9.1 & 8.6 & 4.99 & 0.0 & 31.1 \\
\hline Seeds, kg & 6.1 & 4.4 & 6.96 & 0.0 & 50.8 \\
\hline Animals, $\mathrm{kg}$ & 4.1 & 0.0 & 11.99 & 0.0 & 141.3 \\
\hline Forages, $\mathrm{kg}$ & 12.6 & 0.0 & 62.74 & 0.0 & 636.8 \\
\hline Mineral feeds, $\mathrm{kg}$ & 80.3 & 55.2 & 87.77 & 0.0 & 640.0 \\
\hline Concentrates, $\mathrm{kg}^{\mathrm{a}}$ & 310.1 & 258.3 & 223.66 & 1.8 & 1413.6 \\
\hline Concentrates, $\mathrm{kg} \mathrm{ha}^{-1}$ & 7.3 & 6.2 & 4.96 & 0.0 & 26.5 \\
\hline Bedding, $\mathrm{kg}$ & 1.9 & 0.5 & 5.43 & 0.0 & 74.2 \\
\hline Total P import, kg & 842.0 & 777.9 & 472.78 & 62.0 & 2646.9 \\
\hline Total P import, $\mathrm{kg} \mathrm{ha}^{-1}$ & 18.5 & 17.0 & 7.87 & 1.7 & 51.1 \\
\hline \multicolumn{6}{|l|}{ P export } \\
\hline Manure, kg & 34.1 & 0.0 & 84.15 & 0.0 & 600.0 \\
\hline Crops, kg & 71.7 & 0.0 & 184.75 & 0.0 & 1471.2 \\
\hline Animals, $\mathrm{kg}$ & 40.7 & 35.7 & 29.85 & 0.0 & 195.8 \\
\hline Milk, kg & 170.2 & 156.4 & 79.67 & 22.6 & 471.1 \\
\hline Total $\mathrm{P}$ export, $\mathrm{kg}$ & 316.7 & 238.4 & 244.18 & 44.3 & 1633.3 \\
\hline Total P export, $\mathrm{kg} \mathrm{ha}^{-1}$ & 6.8 & 5.8 & 3.84 & 1.8 & 29.4 \\
\hline P balance, $\mathrm{kg}$ & 525.3 & 462.2 & 376.31 & -200.5 & 2254.7 \\
\hline P balance, $\mathrm{kg} \mathrm{ha}^{-1}$ & 11.7 & 11.1 & 7.20 & -4.1 & 39.5 \\
\hline
\end{tabular}

ancludes imported grain, by-products, commercial concentrates and protein supplements 
Vol. 14 (2005): 166-180.
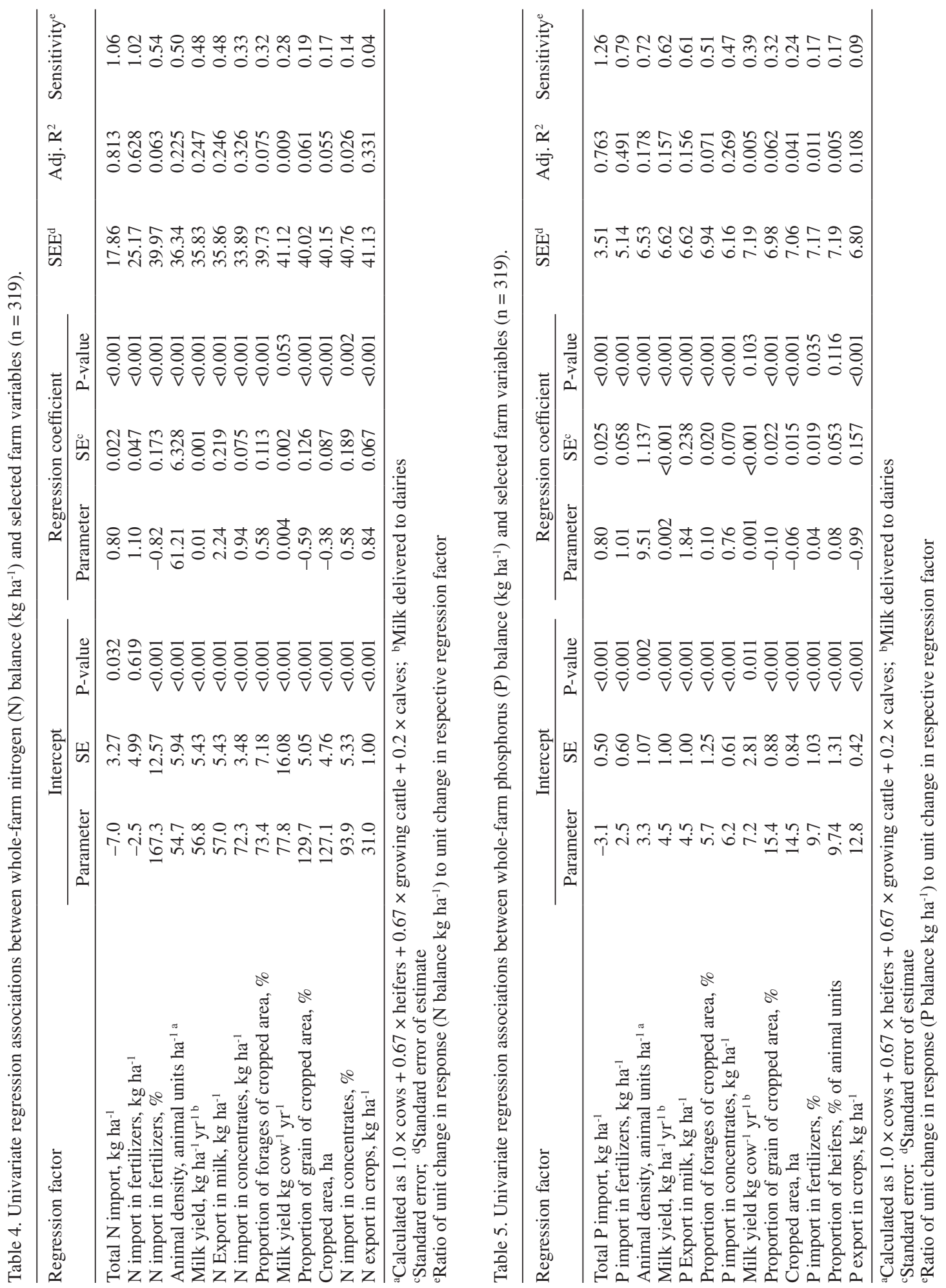
In general, total imported $\mathrm{N}\left(\mathrm{kg} \mathrm{ha}^{-1}\right)$ was strongly correlated to N-WFB $\left(\mathrm{R}^{2}=0.813\right)$. The slope of the regression was $0.80( \pm 0.022)[ \pm$ standard error (SE)], indicating that the efficiency of utilization of purchased $\mathrm{N}$ was only 0.20 . The regression slopes for imported fertilizer and concentrate $\mathrm{N}$ were $1.10( \pm 0.047)$ and $0.94( \pm 0.075)$. Exported $N$ in milk and crops explained markedly less $\left(\mathrm{R}^{2}=\right.$ 0.246 and 0.331 , respectively) of the variation in $\mathrm{N}$-WFB than imported $\mathrm{N}$. On average, every $\mathrm{kg}$ of milk $\mathrm{N}$ exported from the farms increased N-WFB by $2.24 \mathrm{~kg} \mathrm{ha}^{-1}$.

Milk yield ( $\mathrm{kg}$ per cow $\mathrm{yr}^{-1}$ ) was weakly but significantly $(\mathrm{P}=0.053)$ correlated with $\mathrm{N}-\mathrm{WFB}$ $\left(\mathrm{R}^{2}=0.009\right)$. A $1000 \mathrm{~kg}$ increment in milk yield increased N-WFB by $4 \mathrm{~kg} \mathrm{ha}^{-1}$. Animal density was notably better correlated with N-WFB than milk yield, explaining $22.5 \%$ of the variation. The regression slope implied that N-WFB increased by $62.1 \mathrm{~kg} \mathrm{ha}^{-1}$ per unit increase in animal density.

Total imported $\mathrm{P}\left(\mathrm{kg} \mathrm{ha}^{-1}\right)$ explained proportionally 0.763 of the variation in P-WFB (Table 5). The whole-farm utilization efficiency was similar to that of $\mathrm{N}$, as indicated by the regression slope $0.80( \pm 0.025)$. Each $\mathrm{kg}$ of imported $\mathrm{P}$ in fertilizers or concentrates increased P-WFB by 1.01 and 0.76 $\mathrm{kg} \mathrm{ha}^{-1}$, respectively. Exported P in crops $\left(\mathrm{kg} \mathrm{ha}^{-1}\right)$ decreased P-WFB by $0.99 \mathrm{~kg} \mathrm{ha}^{-1}$ and one $\mathrm{kg}$ exported $\mathrm{P}$ in milk increased P-WFB by $1.84 \mathrm{~kg} \mathrm{ha}^{-1}$. Increases in milk yield ( $\mathrm{kg}$ per cow or $\mathrm{kg} \mathrm{ha}^{-1}$ ) or animal density all increased P-WFB, the effect of animal density being clearly the strongest.

A rather close relationship existed between WFB for $\mathrm{N}$ and $\mathrm{P}\left(\mathrm{R}^{2}=0.342\right.$, Fig. 1). This relationship tended to be curvilinear, i.e. at an N-WFB of $100 \mathrm{~kg} \mathrm{ha}^{-1}$ a $10 \mathrm{~kg}$ marginal increase in N-WFB increased P-WFB by about $1 \mathrm{~kg} \mathrm{ha}^{-1}$, but at surpluses of $200 \mathrm{~kg} \mathrm{~N}^{-1}$ the respective marginal change in P-WFB was $1.35 \mathrm{~kg} \mathrm{ha}^{-1}$.

\section{Effect of production intensity and farm type on nutrient surplus}

Farm type and production intensity significantly affected nutrient balances (Fig. 2). On L vs. H

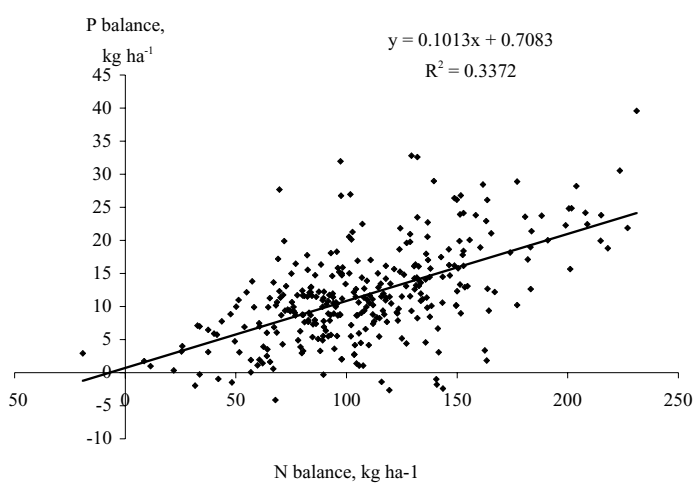

Fig. 1. The relationship between whole-farm $\mathrm{N}$ and $\mathrm{P}$ balance on Finnish dairy farms $(\mathrm{n}=319)$.

farms the surplus for $\mathrm{N}$ was 91 vs. $117(\mathrm{P}<0.001)$ and for $\mathrm{P} 9.4$ vs. $12.3(\mathrm{P}<0.001) \mathrm{kg} \mathrm{ha}^{-1}$. Specialised $\mathrm{M}$ farms had higher nutrient surpluses than $\mathrm{C}$ farms exporting both crops and milk (N: 109 vs. 85; P: 12 vs. $\left.7 \mathrm{~kg} \mathrm{ha}^{-1}, \mathrm{P}<0.001\right)$.

The schematic presentations in Figures 3 and 4 summarise the surpluses of $\mathrm{N}$ and $\mathrm{P}$ in response to the nutrient IM ratio, using regression equations estimated from the present data. Both $\mathrm{N}$ and $\mathrm{P}$ surpluses increased significantly $(\mathrm{P}<0.001)$ with increasing IM ratio on $\mathrm{M}$ farms (Fig. 3a). On $\mathrm{C}$ farms (Fig. 3b), the effect of IM ratio on nutrient surpluses was less pronounced and non-significant $(\mathrm{P}$ $>0.1$ ). The estimated surpluses with no feed import were about 70 and $5 \mathrm{~kg} \mathrm{ha}^{-1}$ for $\mathrm{N}$ and $\mathrm{P}$, respectively.

The surplus of nutrients in response to IM ratio increased more on $\mathrm{H}$ farms ( $\mathrm{I} \geq 4000 \mathrm{~kg} \mathrm{ha}^{-1}$ ) than on $\mathrm{L}$ farms $\left(\mathrm{I}<4000 \mathrm{~kg} \mathrm{ha}^{-1}\right.$, Figs $4 \mathrm{a}$ and b). However, on farms with high I, a lower nutrient surplus was estimated, provided that no feed nutrients were imported. Consequently, P surplus was estimated to be close to zero $(\mathrm{P}>0.1$ for intercept) on $\mathrm{H}$ farms with no feed $\mathrm{P}$ import. 
Vol. 14 (2005): 166-180.

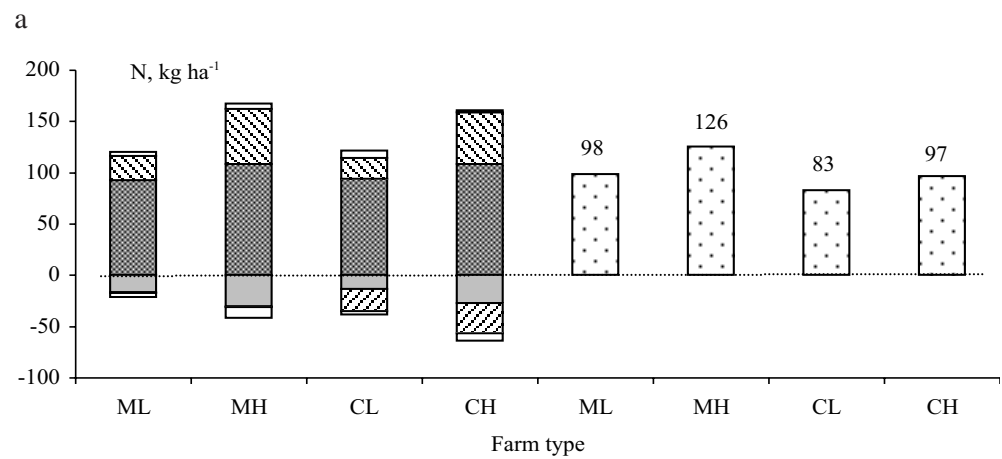

圆Fertilizers $₫$ Feeds $\square$ Other $\square$ Milk $\square$ Crops $\square$ Other $\square$ Balance

Fig. 2. The effect of nutrient export ratio $(\mathrm{EX}<0.25=$ mainly livestock "M"; $\mathrm{EX} \geq 0.25=$ combined milk \& crop "C") and milk production intensity (export < $4000 \mathrm{~kg} \mathrm{ha}^{-1}=$ low "L"; export $\geq$ $4000 \mathrm{~kg} \mathrm{ha}^{-1}=$ high " $\mathrm{H}$ ") on average nitrogen $(\mathrm{N} ; \mathrm{n}=103,150,51$ and 15 for ML, MH, CL and $\mathrm{CH}$, respectively) and phosphorus $(\mathrm{P}$; $\mathrm{n}=101,146,53$ and 19 for ML, $\mathrm{MH}, \mathrm{CL}$ and $\mathrm{CH}$, respectively) exports, imports and whole-farm balances. b

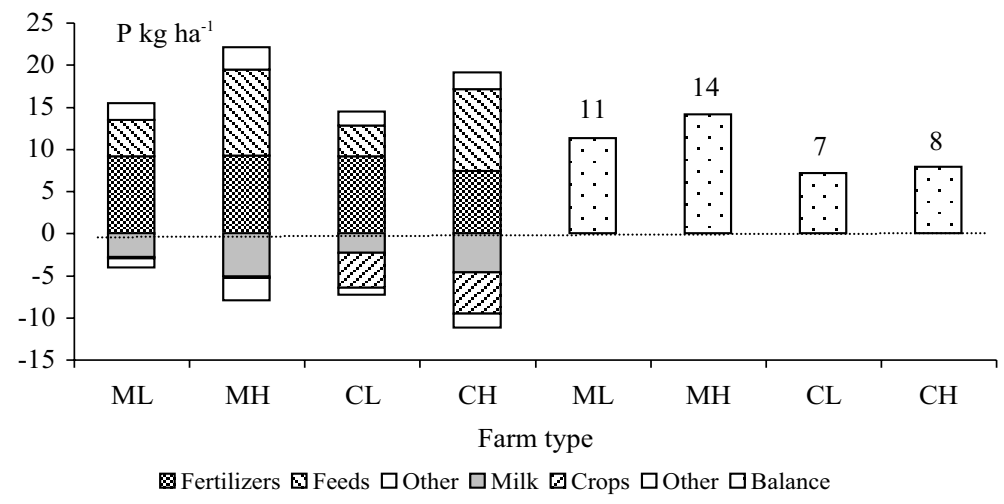

\section{Discussion}

\section{Validity of the dataset}

It is generally accepted that whole-farm nutrient balances are satisfactory descriptors of potential nutrient load from milk production to the environment (Van Keulen et al. 2000, Schröder et al. 2003). In addition, the uncertainties for WFB are obviously less than for soil and soil system nutrient balances (Oenema et al. 2003). WFB for $\mathrm{N}$ and P on Finnish dairy farms for the year 2002, reported here are evidently not very accurate if the results are interpreted for one single farm, due to differences in e.g. crop management, environmental conditions and crop yields between seasons, as well as changes in nutrient stores and herd size.
Moreover, no information was available on subsystems within farms. However, this dataset is adequate to study average nutrient balances on dairy farms in Finland, since it included a large number of farm-scale observations ( $n=319$, equivalent to $1.6 \%$ of the Finnish dairy farms in 2002), covering the whole of Finland. The farms included in this dataset were somewhat larger than the average in 2002 (see Table 1), judging from total cropping area and herd size. Moreover, in the sample there was a slight bias towards larger farms, i.e. the median values were slightly lower than the mean values for herd size and total cropping area. However, the median and mean values for the most important variables in relation to nutrient balances, i.e. animal density and milk yield ( $\mathrm{kg}$ per cow or $\mathrm{kg}$ ha $^{-1}$ ) were close (Table 1 ). 


\section{Whole-farm N-balance}

Average N-WFB in this study was $108.6 \mathrm{~kg} \mathrm{ha}^{-1}$, resulting from the difference between total mean import of 144 and export of $36 \mathrm{~kg} \mathrm{ha}^{-1}$. Actual soil $\mathrm{N}$ surplus may be somewhat higher, since biological fixation and atmospheric deposition were not considered herein. According to Räike et al. (2004) the average $\mathrm{N}$ deposition in Finland may vary between 4-6 $\mathrm{kg} \mathrm{ha}^{-1}$. In this study $\mathrm{N}$ surplus was higher than reported by Väisänen $(1996,67 \mathrm{~kg}$ $\left.\mathrm{ha}^{-1}\right)$ for a limited dataset $(\mathrm{n}=4)$, but a larger dataset (Poikela 2000, $n=456$ ) of conventional dairy farms in North-Eastern Finland between 19951999 showed similar N-WFB (110 kg ha-1). The Finnish results for dairy farms are markedly lower than those calculated for Sweden (Swensson 2002, 161-187 kg ha-1) and the Netherlands (Fraters et al. 2003, > $200 \mathrm{~kg} \mathrm{ha}^{-1}$ ). This is most probably due to the higher production intensities in these countries, associated with higher animal densities and the necessary higher feed $\mathrm{N}$ imports. This is supported by the present results, showing that $\mathrm{N}$ surplus significantly $(\mathrm{P}<0.001)$ increased with increasing animal density and milk yield per cropped farm area (Table 4). In the Netherlands, for example, milk output per cropped farm area may be $10000-12000 \mathrm{~kg} \mathrm{ha}^{-1}$ on typical dairy operations, resulting in at least $200 \mathrm{~kg} \mathrm{ha}^{-1} \mathrm{~N}$ surplus even though special measures to improve whole-farm nutrient utilization are adopted (Van Keulen et al. 2000). When extrapolating the present data to a

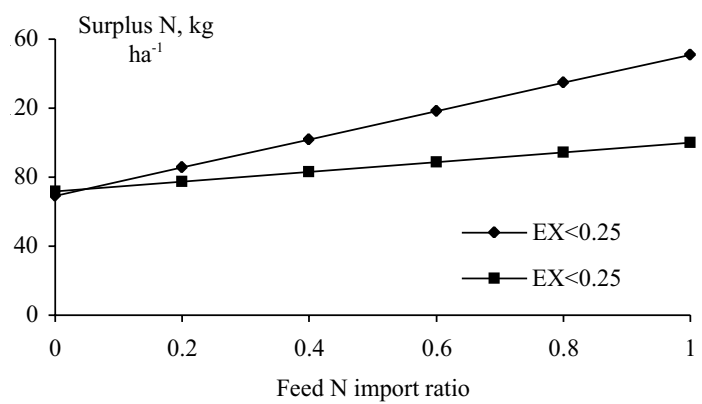

b

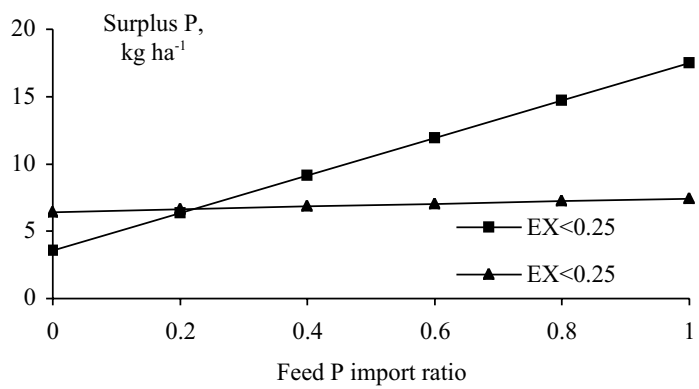

Fig. 3. The effect of feed import ratio (IM = ratio of estimated feed nutrient usage by dairy herd to imported feed nutrient) and crop export ratio (EX = ratio of exported nutrient in crops to total export) on the whole-farm $\mathrm{N}$ (a) or P (b) surplus.
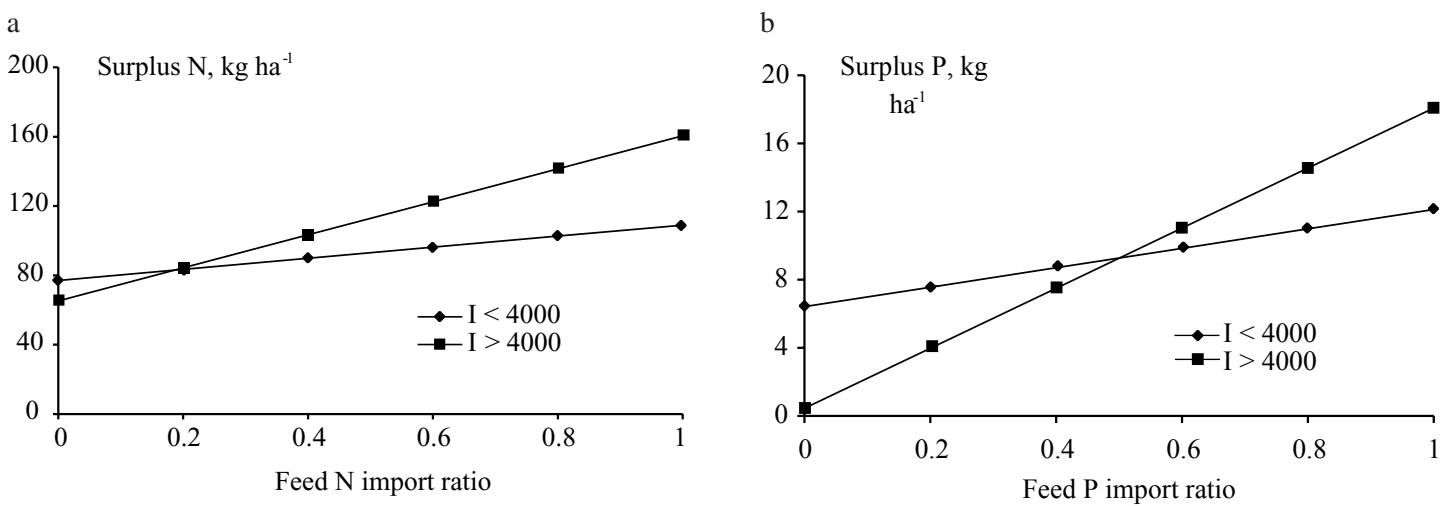

Fig. 4. The effect of feed import ratio (IM = ratio of estimated feed nutrient usage by dairy herd to imported feed nutrient) and milk production intensity (I, kg ha-1) on the whole-farm $\mathrm{N}$ (a) or $\mathrm{P}$ (b) surplus. 
Vol. 14 (2005): 166-180.

comparable intensity, average N-WFP increased to about $200 \mathrm{~kg} \mathrm{ha}^{-1}$. Compared to the soil surface $\mathrm{N}$ balance estimated for arable land in Finland (OECD 2001, Antikainen et al. 2005, figures varying from 29 to $64 \mathrm{~kg} \mathrm{ha}^{-1}$ ), the present and previously published N-WFB values for dairy farms are substantially higher, which highlights the problems in $\mathrm{N}$ utilization efficiency within animal agriculture. Comparison between mainly livestock farms and those exporting crop products implies that $\mathrm{N}$ surplus is easier to control within mixed crop and livestock systems than in livestock systems (N-WFP 115 vs. $86 \mathrm{~kg} \mathrm{ha}^{-1}$, see Figs 2-4). This is in agreement with the results of Swensson (2003), while Bos and van de Ven (1999) found only a small difference in nutrient utilisation between specialised vs. mixed farming systems.

Of the selected farm variables studied (Table 4), total $\mathrm{N}$ imports explained best the variation in N-WFB $\left(\mathrm{R}^{2}=0.813\right)$, followed by fertilizer and concentrate $\mathrm{N}$ imports $\left(\mathrm{R}^{2}=0.628\right.$ and 0.326 , respectively). This implies that improving fertilizer $\mathrm{N}$ utilization by increasing crop yields and/or avoiding excess use and/or better timing of application, in combination with lower feed $\mathrm{N}$ imports is the most efficient means for decreasing $\mathrm{N}$ surplus. This is consistent with the sensitivity coefficients (i.e. ratio of unit change in surplus to unit change in the measure adopted) reported by Van Bruchem et al. (1999). They reported that the most effective intervention in decreasing $\mathrm{N}$ surplus is reducing fertilizer $\mathrm{N}$ import (0.65), followed by more efficient soil $\mathrm{N}$ utilization $(0.25)$ and reducing feed $\mathrm{N}$ import (0.24). The respective sensitivity coefficients for fertilizer and feed $\mathrm{N}$ import in the present study were 1.02 and 0.33 (Table 4). In addition to $\mathrm{N}$ import variables, both variables describing production intensity (animal density and milk export in $\mathrm{kg} \mathrm{ha}^{-1}$ ) explained the variation in $\mathrm{N}$-WFB relatively well $\left(\mathrm{R}^{2}=0.225\right.$ and 0.247 , respectively) and were also rather sensitive factors (coefficients 0.50 and 0.48 , respectively). When fertilizer $\mathrm{N}$ import was used together with animal density or concentrate $\mathrm{N}$ import in a bi-variate regression model (results not shown), the sensitivity of the latter (both 0.22) decreased and that of fertilizer $\mathrm{N}$ import remained rather similar (0.89-0.92).
This further highlights the importance of fertilizer $\mathrm{N}$ utilization efficiency in avoiding high $\mathrm{N}$ surplus.

It has often been postulated that increasing milk yield per cow would improve nutrient utilization efficiency both at animal and farm level. However, the present results showed that $\mathrm{N}$ surplus tended to increase $\left(4 \mathrm{~kg} \mathrm{ha}^{-1}, \mathrm{P}=0.053\right)$ in response to $1000 \mathrm{~kg}$ higher milk yield per cow and year. However, this was due to the positive correlation between milk yield per cow and concentrate and/ or fertilizer import per ha. A meta-analysis based on a large dataset of published milk production studies on dairy cows showed that $\mathrm{N}$ utilization efficiency per cow is negatively correlated with dietary $\mathrm{N}$ concentration (Huhtanen et al., unpublished results). Consequently, improvements in $\mathrm{N}$ feeding efficiency can be achieved only if dietary $\mathrm{N}$ concentration is not increased. This was evidently not the case in this study, since concentrate $\mathrm{N}$ import per animal unit increased simultaneously with milk yield per cow. When milk yield (1 kg per cow $\mathrm{yr}^{-1}$ ), animal density and concentrate $\mathrm{N}$ import per animal unit were used in a tri-variate regression analysis, the effect of milk yield on $\mathrm{N}$ surplus was slightly negative but non-significant $(-0.0003 \mathrm{~kg}$ $\mathrm{ha}^{-1}, \mathrm{P}>0.5$ ) and rather insensitive (sensitivity coefficient $<0.05$ ). This result is in good agreement with Van Bruchem et al. (1999) who reported that $\mathrm{N}$ surplus at farm scale was not very sensitive to improved herd $\mathrm{N}$ utilization efficiency. Martin and Seeland (1999) estimated by simulation study that increasing milk yield per cow by genetic improvement of dairy cattle would lead to higher $\mathrm{N}$ emissions per cow or $\mathrm{kg}$ milk. They concluded that theoretical improvements in dairy herd $\mathrm{N}$ utilization associated with improved genetic merit of cows may be hampered by the limited intake capacity leading to higher requirement of dietary $\mathrm{N}$ concentration.

The most important environmental risk following inefficient $\mathrm{N}$ use in dairy farming is that of nitrate- $\mathrm{N}$ leaching to groundwater, lakes and rivers. The key component in the risk for long-term nitrate leaching is a positive soil $\mathrm{N}$ balance, which is further mediated by type of soil, crop and farm management, as well as climatic factors (Salo and 
Turtola, unpublished results). According to Schröder et al. (2003) N-WFB provides a relatively responsive and moderately goal-oriented indicator for nitrate leaching, but to identify the exact scope for improvement at farm scale, a careful analysis of sub-balances within the farm is needed (i.e. $\mathrm{N}$ utilization efficiencies from soil-N to crop- $\mathrm{N}$, from feed-N to milk- $\mathrm{N}$ and from manure- $\mathrm{N}$ to soil-N). These sub-systems need urgently to be studied also for Finnish dairy farms, and subsequently, models to control them may be constructed as demonstrated by Dou et al. (1996). Kohn et al. (1997) studied the impacts of sub-processes within intensive dairy farms and found that improving herd or soil N-efficiencies by $50 \%$ would decrease N-WFB by 48 or $59 \%$, respectively. However, these improvements in efficiency estimates may not represent the true sensitivity of different measures, since responses in whole-farm $\mathrm{N}$ efficiency were not related to realistic changes in sub-processes. In Finland, for example, a typical dairy herd $\mathrm{N}$ utilization efficiency is $0.25-0.30$. Achieving a $50 \%$ improvement would be unrealistic even though no additional protein concentrates were fed (Huhtanen et al., unpublished results).

While total $\mathrm{N}$ utilization of a fixed farming system is the integrated effect of the efficiencies in the various sub-systems within a farm, many strategic choices have an overwhelming effect. Schröder et al. (2003) pointed out that animal density, production intensity and specialisation of the production system are the most important strategic factors, which also significantly affected $\mathrm{N}$ surplus in this study (Table 4, Figs 2-4). However, these factors explained less than half of the variation in N-WFP, which may indicate that a considerable variation exists in $\mathrm{N}$ conversion efficiencies within farm sub-systems for a given farm type and production intensity. Based on a model study, Kuipers and Mandersloot (1999) concluded that N leaching could be best controlled with a combination of several measures, including more efficient fertilizer $\mathrm{N}$ use, restricted grazing and better balanced diets for dairy cows. Nevertheless, the present data and other published studies (e.g. Van Bruchem et al. 1999, Schröder et al. 2003, Spears et al. 2003a, Swensson 2003) indicate that specialised modern dairy farms with very high production intensity combined with high feed IM ratio are often less efficient in $\mathrm{N}$ utilization at a whole-farm scale than mixed livestock and crop production at moderate production intensity.

\section{Whole-farm P-balance}

Average $\mathrm{P}$ surplus (11.7 $\left.\mathrm{kg} \mathrm{ha}^{-1}\right)$ in the present study was similar to data reported before for dairy farms in Finland (Väisänen 1996, 5-32 kg ha-1; Poikela 2000, $13.2 \mathrm{~kg} \mathrm{ha}^{-1}$ ). The estimated average soil $\mathrm{P}$ balance for arable land (Antikainen et al. 2005) corresponds to the value observed in this study (13 kg ha-1), although long-term statistics (Ministry of Agriculture and Forestry 2004) suggest that soil $\mathrm{P}$ balances are reduced by $60-70 \%$ from 1990 until 2002. The most important reason is evidently reduced fertilizer use, since P fertilization has decreased from 31 to $10 \mathrm{~kg} \mathrm{ha}^{-1}$ within that time period (Niemi and Ahlstedt 2003). Nevertheless, in contrast to N-WFB, P-WFP should be close to the actual soil $\mathrm{P}$ balance because volatile losses and biological fixation do not play a role. The background atmospheric $\mathrm{P}$ deposition due to rainfall in Finland is estimated to be quite small (1.4 $\mathrm{kg} \mathrm{ha}^{-1}$; Järvinen and Vänni 1998).

Total $\mathrm{P}$ import per ha explained most of the variation in P-WFB $\left(R^{2}=0.763\right.$, Table 5), followed by $\mathrm{P}$ import in fertilizers $\left(\mathrm{R}^{2}=0.491\right)$ and concentrates $\left(\mathrm{R}^{2}=0.269\right)$. Moreover, $\mathrm{P}$ surplus was very sensitive to total $\mathrm{P}$ (coefficient 1.26) and fertilizer $\mathrm{P}$ imports (0.79) compared to concentrate $\mathrm{P}$ import (0.47). In contrast to the results of Van Keulen et al. (2000) and Spears et al. (2003), in the Finnish data fertilizer $\mathrm{P}$ import was proportionally higher than that in concentrates (Table 3 ). When both fertilizer and concentrate $\mathrm{P}$ imports were used in a bivariate regression model, the slope for fertilizer $P$ remained unchanged (0.97) and that of concentrate P was slightly lower (0.69) compared to the slopes in the univariate regressions (Table 5). This further suggests that reducing fertilizer $\mathrm{P}$ use by improving manure $\mathrm{P}$ utilization in crop production would be the most successful strategy in improving P-WFB in Finnish conditions. In agreement 
Vol. 14 (2005): 166-180.

with our data, Van Bruchem et al. (1999) estimated the highest sensitivity coefficient for fertilizer $P$ import (0.55), but that of feed import (0.36) was almost the same. However, in contrast to the present data, their work involved also interpretation of $\mathrm{P}$ conversion efficiencies from soil to crop and from feed to milk, which also need to be studied in Finland.

Typical P surpluses for intensive dairy operations in the Netherlands (Van Bruchem et al. 1999, van Keulen et al. 2000) are much higher (20-30 kg $\mathrm{ha}^{-1}$ ) than the results in this study (Table 3). However, when the correlation between intensity and $\mathrm{P}$ surplus is extrapolated to an intensity level comparable to that in the Netherlands $(11000-13000 \mathrm{~kg}$ $\left.\mathrm{ha}^{-1}\right)$, a similar P surplus (25-30 $\left.\mathrm{kg} \mathrm{ha}^{-1}\right)$ is expected. Recent data from Sweden (Swensson 2003) indicate essentially lower values $\left(5-7 \mathrm{~kg} \mathrm{ha}^{-1}\right)$, although milk production intensity was higher (6 600-6 $900 \mathrm{~kg} \mathrm{ha}^{-1}$ ) than the average in the present study. On farms with low vs. high production intensity (mean milk export 2950 vs. $5660 \mathrm{~kg}$ ha $^{-1}$ ) P surpluses were 9.9 vs. $13.4 \mathrm{~kg} \mathrm{ha}^{-1}$ (Fig. 2), resulting evidently from higher animal density (0.67 vs. 1.08$)$, feed $P$ import ratio (0.59 vs. 0.73 ) and concentrate P import (4.1 vs. $10.2 \mathrm{~kg} \mathrm{ha}^{-1}$ ). Moreover, the present data suggest an interaction between farm type and production intensity. In contrast to specialised dairy farms, $\mathrm{P}$ surplus did not increase in response to higher intensity in the mixed crop/livestock systems (Figures $2 b, 3 b$ ), in spite of higher feed P IM ratio with higher intensity irrespective of farm type. In agreement with Swensson (2003) and Spears et al. (2003b) our data (Fig. 2) indicate that $\mathrm{P}$ surpluses are easier to control in combined crop/livestock systems than in specialised milk production systems. This is evidently a consequence of better utilization of manure $\mathrm{P}$ in crop production. Kuipers and Mandersloot (1999) concluded that a zero P balance might be possible also in intensive milk production, provided that excess $\mathrm{P}$ in feed is avoided and manure is exported to $\mathrm{P}$-deficient regions. The latter may be impractical under Finnish conditions, because the area with specialised crop production, close enough to regions with intensive milk production is limited. However, the present results suggest that a significant decrease in $\mathrm{P}$ surplus even without manure export could be achieved $\left(0-5 \mathrm{~kg} \mathrm{ha}^{-1}\right)$, provided that the feed P IM ratio can be kept low, combined with moderate milk export per arable land (see Figs 3 and 4).

The present data suggest a tendency towards higher $\mathrm{P}$ surpluses with higher milk yields per cow (0.6 kg ha ${ }^{-1}$ per $1000 \mathrm{~kg}$ per $\mathrm{y}, \mathrm{P}=0.103$, Table 5). The slope of milk yield remained similar $(\mathrm{P}=$ 0.064) in a tri-variate regression model where the effects of animal density and feed $\mathrm{P}$ imports per animal unit were taken into account (results not shown). This may indicate that increases in milk yield per cow are associated with higher dietary $\mathrm{P}$ intake, which hampers the expected improvements in dairy herd and total farm P utilization. In agreement with this, Yrjänen et al. (2003) showed increased faecal $\mathrm{P}$ excretion in response to higher milk yield per cow due to positive association with concentrate proportion in the diet. Grass silage contains typically about 3 and normal concentrate mixture 5-7 $\mathrm{g}(\mathrm{kg} \mathrm{DM})^{-1}$ of P.

Recent studies (Wu et al. 2001) clearly suggest that dietary $\mathrm{P}$ concentration for dairy cows can be significantly reduced to about $3.5 \mathrm{~g}(\mathrm{~kg} \mathrm{DM})^{-1}$ in comparison to previous feeding standards and existing practise. According to Yrjänen et al. (2003) the present dietary $\mathrm{P}$ concentration for dairy cows in Finland is close to $5 \mathrm{~g}(\mathrm{~kg} \mathrm{DM})^{-1}$, suggesting an obvious potential for reduction. Unfortunately, these efforts may be seriously confounded by increased milk yield per cow, which often is associated with a high proportion of concentrates and $\mathrm{CP}$ concentration in the ration leading to inevitably excess $\mathrm{P}$ concentrations in the diet, albeit no additional P from mineral feeds is used (Yrjänen et al. 2003). Additionally, a trend towards more concentrate-rich diets most probably increases the proportion of soluble $\mathrm{P}$ in manure (Wu et al. 2000).

\section{Conclusions}

Based on a one-year ad-hoc study on Finnish dairy farms $(n=319)$, average $( \pm S D)$ whole-farm nutri- 
ent balances for $\mathrm{N}$ and $\mathrm{P}$ were $109( \pm 41.3)$ and 12 $( \pm 7.2) \mathrm{kg} \mathrm{ha}^{-1}$. Production intensity $\left(\mathrm{kg}\right.$ milk ha $\left.{ }^{-1}\right)$, farm type (specialised milk production vs. combined crop and milk production) and feed import ratio significantly affected the nutrient surpluses per ha. The most sensitive factors affecting wholefarm balances for $\mathrm{N}$ and $\mathrm{P}$ were total nutrient and fertilizer import per ha, followed by animal density, milk export per ha and concentrate import per ha. It is concluded that nutrient surpluses on dairy farms in Finland are substantially lower than those in areas with intensive production in western Europe. However, when surpluses are extrapolated to comparable production intensities, similar nutrient surpluses are expected. To find sensitive and effective means for improving nutrient utilization on dairy farms, the conversion efficiencies from feed to milk, from manure to soil and especially from soil to crop within farms need urgently to be studied further.

\section{References}

Antikainen, R., Lemola, R., Nousiainen, J.I., Sokka, L., Esala, M., Huhtanen, P. \& Rekolainen, S. 2005. Stocks and flows of nitrogen and phosphorus in the Finnish food production and consumption system. Agriculture, Ecosystems \& Environment 107: 287-305.

ARC 1980. The nutrient requirements of ruminant animals. Technical review by an acricultural council working party. Commonwealth Agricultural Bureaux, The Gresham Press, Old Woking, Surrey, UK. 351 p.

Bos, J.F.F.P. \& van de Ven, G.W.J. 1999. Mixing specialized farming systems in Flevoland (The Netherlands): Agronomic, environmental and socio-economic effects. Netherlands Journal of Agricultural Science 47: 185200.

Dou, Z., Kohn, R.A., Ferguson, J.D., Boston, R.C. \& Newbold, J.D. 1996. Managing nitrogen on dairy farms: an integrated approach I. Model description. Journal of Dairy Science 79: 2071-2080.

Ekholm, P., Turtola, E., Grönroos, J., Seuri, P. \& Ylivainio, K. 2005. Phosphorus loss from different farming systems estimated from soil surface phosphorus balance. Agriculture, Ecosystems and Environment 110: 266-278.

Farm Register 2002. Information Centre of the Ministry of Agriculture and Forestry, Helsinki, Finland. 130 p. Available on the Internet: http://matilda.mmm.fi/servlet/ page?_pageid=504,193\&_dad=portal30\&_schema= PORTAL30
Fraters, D., Boumans, L., Van Leeuwen, T. \& De Hoop, W. 2003. Results of 10 years of monitoring nitrogen in the sandy regions in the Netherlands. In: Bruen, M. (ed.). Diffuse pollution and basin management. Proceedings of the 7th International Specialised IWA Conference, Dublin, Ireland. ISBN 1902277767. 4 Volumes. 1140 p. Cited 15 December 2004. Available on the Internet: http://www.ucd.ie/dipcon/proceedings.htm

Høgaas Eide, M. 2002. Life cycle assessment (LCA) of industrial milk production. The International Journal of Life Cycle Assessment 7, 2: 115-126.

Järvinen, O. \& Vänni, T. 1998. Sadeveden pitoisuus- ja laskeuma-arvot Suomessa vuonna 1996. Suomen Ympäristökeskuksen moniste Nro 120. Suomen Ympäristökeskus, Helsinki. 67 p.

Kohn, R.A., Dou, Z., Ferguson, J.D. \& Boston, R.C. 1997. A sensitivity analysis of nitrogen losses from dairy farms. Journal of Environmental Management 50: 417-428.

Kuipers, A. \& Mandersloot, F. 1999. Reducing nutrient losses on dairy farms in the Netherlands. Livestock Production Science 61: 139-144.

Martin, S. \& Seeland, G. 1999. Effects of specialisation in cattle production on ecologically harmful emissions. Livestock Production Science 61: 171-178.

Ministry of Agriculture and Forestry 2004. Mid-term evaluation of the Horizontal Rural Development Programme. Publications of the Ministry of Agriculture and Forestry 1/2004. Helsinki. 272 p. (in Finnish with English summary).

Niemi, J. \& Ahlstedt, J. (eds.). 2003. Finnish agriculture and rural industries 2003. MTT Economic Research, Publications $103.94 \mathrm{p}$.

OECD 2001. OECD national soil surface nitrogen balances: preliminary estimates 1985-1997. Paris, France. Cited 2 Dec 2004. Available on the Internet: http://www.oecd. org/agr/env/indicators.htm

Oenema, O., Kros, H. \& DeVries, W. 2003. Approaches and uncertainties in nutrient budgets: implications for nutrient management and environmental policies. European Journal of Agronomy 20: 3-16.

Poikela, T. 2000. Lypsykarjatilojen ravinnetaseet Aito ympäristö -projektissa vuosina 1995-2000. In: Ahtela, I. (ed.). Kestävä maatalous Vantaanjoella. Ravinnetaseseminaari Helsingissä 26.9.2000. Uudenmaan ympäristökeskuksen monisteita nro. 75. 45 p. (in Finnish).

Räike, A., Gralund, K. \& Ekholm, P. 2004. Maatalouden ravinnekuormitus ja sen vesistövaikutukset - arviointi seuranta-aineistojen avulla. Ravinnekuormitus. Executive summary: Nutrient load from agricultural land and its effects in surface waters - evaluation based on monitoring data. Nutrient loading. In: Turtola, E. \& Lemola, R. (eds.). Maatalouden ympäristötuen seuranta, MYTVAS 2, osahankkeiden 2-7 väliraportit 2000-2003. Maa- ja elintarviketalous 59: 97-109. (in Finnish).

Räike, A., Pietiläinen, O.-P., Rekolainen, S., Kauppila, P., Pitkänen, H., Niemi, J., Raateland, A. \& Vuorenmaa, J. 2003. Trends in phosphorus, nitrogen and chlorophyll-a concentrations in Finnish rivers and lakes in 19752000. The Science of the Total Environment 310: 4759.

Schröder, J.J., Aarts, H.F.M., ten Berge, H.F.M., van KeuIen, H. \& Neeteson, J.J. 2003. An evaluation of whole- 
Vol. 14 (2005): 166-180.

farm nitrogen balances and related indices for efficient nitrogen use. European Journal of Agronomy 20: 3344.

Spears, R.A., Kohn, R.A. \& Young, A.J. 2003a. Whole-farm nitrogen balance on western dairy farms. Journal of Dairy Science 86: 4178-4186.

Spears, R.A., Young, A.J. \& Kohn, R.A. 2003b. Whole-farm phosphorus balance on western dairy farms. Journal of Dairy Science 86: 688-695.

Swensson, C. 2003. Analyses of mineral element balances between 1997 and 1999 from dairy farms in the south of Sweden. European Journal of Agronomy 20: 63-69.

Tuori, M., Kuoppala, K., Valaja, J., Aimonen, E., Saarisalo, E. \& Huhtanen, P. 2002. Rehutaulukot ja ruokintasuositukset 2002. Updated 28 Jun 2002. Cited 13 Oct 2003. Available on the Internet: http://www.agronet.fi/rehutaulukot/ (in Finnish).

Väisänen, J. 1996. Ravinteiden kauppataseet nautakarjatilojen ravinteidenkäytön kuvaajina. Abstract: Farm-gate balances as indicators of nutrient utilization on dairy farms. Agrifood Research Publications, Serie A 8. MTT Agrifood Research Finland, Jokioinen. 54 p. (in Finnish).

Van Bruchem, J., Schiere, H. \& van Keulen, H. 1999. Dairy farming in the Netherlands in transition towards more efficient nutrient use. Livestock Production Science 61: 145-153.

Van Horn, H.H., Newton, C.L. \& Kunkle, W.E. 1996. Ruminant nutrition from an environmental perspective: Fac- tors affecting whole-farm nutrient balance. Journal of Animal Science 74: 3082-3102.

Van Keulen, H., Aarts, H.F.M., Habekotté, B., Van der Meer, H.G. \& Spiertz, J.H.J. 2000. Soil- plant-animal relations in nutrient cycling: the case of dairy farming system 'de Marke'. European Journal of Agronomy 13: 245-261.

Voutilainen, P., Tuhkanen, H.R., Katajajuuri, J.M., Nousiainen, J.I. \& Honkasalo, N. 2003. Emmental-Sinileimajuuston tuotantoketjun ympäristövaikutukset ja parannusmahdollisuudet. Abstract: Environmental impacts and improvement possibilities of Emmental blue-label cheese. Agrifood Research Reports 35. MTT Agrifood Research Finland, Jokioinen. 91 p. (in Finnish).

Wu, Z., Satter, L.D., Blohowiak, A.J., Stauffacher, R.H. \& Wilson, J.H. 2001. Milk production, estimated phosphorus excretion and bone characteristics of dairy cows fed different amounts of phosphorus for two or three years. Journal of Dairy Science 84: 1738-1748.

Wu, Z., Satter, L.D. \& Sojo, R. 2000. Milk production, reproductive performance, and faecal excretion of phosphorus by dairy cows fed three amounts of phosphorus. Journal of Dairy Science 83, 5: 1028-1041.

Yrjänen, S., Nousiainen, J.I., Kytölä, K., Khalili, H. \& Huhtanen, P. 2003. Ruokinnalliset mahdollisuudet parantaa fosforin hyväksikäyttöä maidontuotannossa. In: UusiKämppä, J. et al. (eds.). Lypsykarjataloudesta tulevan ympäristökuormituksen vähentäminen. Maa- ja elintarviketalous 25. p. 13-25. Available on the Internet: http:// www.mtt.fi/met/pdf/met25.pdf (in Finnish). 


\title{
SELOSTUS
}

\section{Typen ja fosforin ravinnetaseet suomalaisilla lypsykarjatiloilla}

\author{
Hanna Virtanen ja Juha Nousiainen \\ Valio Oy ja MTT (Maa- ja elintarviketalouden tutkimuskeskus)
}

\begin{abstract}
Intensiivisessä maidontuotannossa on tärkeää löytää keinoja hehtaarikohtaisten ravinneylijäämien pienentämiseksi. Ravinteiden tilataseet ovat ulkomaisten tutkimusten mukaan yksinkertainen ja käytäntöön soveltuva menetelmä arvioida maidontuotannon aiheuttamaa ravinnepäästöpotentiaalia. Tässä tutkimuksessa laskettiin typen ja fosforin hehtaarikohtaiset porttitaseet suomalaisille lypsykarjatiloille vuoden 2002 tiedoista. Tutkimus suoritettiin kirjekyselynä $(n=1260)$, jonka tuloksena lopulliseen aineistoon saatiin 319 tilahavaintoa. Kyselyyn vastanneista 386 tilasta (vastausprosentti 31 ) poistettiin luonnonmukaisen viljelyn tilat $(\mathrm{n}=16)$, fosforipitoisia kivijauheita käyttäneet tilat $(n=24)$, epätäydellisesti täytetyt kaavakkeet $(\mathrm{n}=8)$ ja poikkeavat havainnot $(\mathrm{n}=19)$. Ravinnetaseet laskettiin tilalle tuotujen ja sieltä vietyjen ravinnemäärien erotuksena. Ilmalaskeumaa $(\mathrm{N}$ ja P), typen haihtumista ja biologista $\mathrm{N}$-sidontaa ei huomioitu. Valittujen tilamuuttujien yhteyttä ravinnetaseeseen tutkittiin regressioanalyysin avulla. Lisäksi valituille tilamuuttujille laskettiin herkkyyskerroin (regressiosuoran kulmakertoimen suhdeluku yhden yksikön muuttumiseen regressiomuuttujan arvossa).
\end{abstract}

Keskimääräinen $( \pm \mathrm{SD})$ porttitase oli typellä 109 $( \pm 41.3)$ ja fosforilla $12( \pm 7.2) \mathrm{kg} / \mathrm{ha}$. Maidontuotannon intensiteetti (kg maitoa hehtaaria kohti), tilan tuotantotapa (maidontuotanto vs. maidontuotanto ja kasvinviljely yhdessä) ja rehuntuontisuhde vaikuttivat ravinnetaseisiin. Herkkyyskertoimien mukaan typen ja fosforin hehtaarikohtaisia taseita voidaan parhaiten hallita pienentämällä kokonaisravinnepanoksia hehtaaria kohden, vähentämällä hehtaarikohtaista lannoitteiden tuontia sekä alentamalla eläintiheyttä, maidontuotannon intensiteettiä sekä väkirehujen tuontia pinta-alaa kohden. Tulosten mukaan ravinteiden ylijäämä on helpommin hallittavissa harjoittamalla tilalla kasvinviljelyä pelkän maidontuotannon lisäksi.

Suomalaisilla lypsykarjatiloilla ravinteiden ylijäämä pinta-alaa kohti on pienempi kuin Keski-Euroopassa intensiivisen maidontuotannon alueilla. Mikäli ravinneylijäämät kuitenkin suhteutetaan keskieurooppalaiselle maidontuotannon intensiteettitasolle, muodostuvat ylijäämät yhtä suuriksi. Jotta löydettäisiin tehokkaita keinoja lypsykarjatilojen ravinteiden käytön parantamiseksi, tarvitaan lisää tutkimusta ravinteiden tehokkaasta hyväksikäytöstä tilatasolla myös Suomessa. Tilan ravinnekierrossa kriittisiksi tekijöiksi muodostuvat silloin ravinteiden siirtäminen satoon, rehun muuttaminen maidoksi ja lannan muuttaminen kasvualustaksi. 